\title{
環境配慮型洗濯におけるペルオキシダーゼを用いた染料退色反応
}

\author{
東 輝 ${ }^{*}$ 森田 みゆき*,\#
}

\section{Decolorization Reaction of Dye Using Peroxidase in Eco-Friendly Washing}

\author{
Akira Higashi* and Miyuki Morita*,\#
}

Hokkaido University of Education Sapporo, Ainosato 5-3-1, Kita-ku, Sapporo 002-8502, Japan

\begin{abstract}
In recent years, eco-friendly washing was spread and neutralization of the washing bath and reduction of bath ratio is in progress. Since there is a possibility that dye transfer occurs during washing, decolorization reaction of dye catalyzed by peroxidase was examined to correspond to eco-friendly washing.

Decolorization conditions that dye transfer of Acid Blue 113 and Direct Blue 71 using $3.4 \times 10^{-8} \mathrm{M}$ horseradish peroxidase (HRP) doesn't occur were $\mathrm{pH} 7.0$ Carmody buffer, over $2.5 \times 10^{-5} \mathrm{M}$ hydrogen peroxide and over $1.0 \times 10^{-5}$ $\mathrm{M} p$-iodophenol. Decolorization reaction of both dyes with sodium percarbonate is conventional bleaching agent didn't proceed substantially. So, practical effectiveness of HRP as a detergent added enzyme was confirmed. When the surfactant concentration was $\mathrm{cmc} \times 1.5$, decolorization rate constant was reduced from $10 \%$ to $40 \%$.
\end{abstract}

(Received 21 December, 2013 ; Accepted 27 Octorber, 2014)

\section{1. 緒 言}

従来，市販衣料用洗濯洗剂には移染防止や，污れの分 解を主な目的として漂白剤が用いられ，一般的には過炭 酸ナトリウムなどの酸素系漂白片が使用されている. 過 炭酸ナトリウムの最適反応条件は高温, 強アルカリ条件 であるが, 高温, 強アルカリでの洗濯は纎維の脆化を引 き起こし[1-2], 高温にするためのエネルギー消費掞よび 強アルカリの排水は環境負荷が大きいなどの課題がある。 また, 高温, 強アルカリの条件下以外では, 漂白効果が 著しく低下し, 本来の目的である移染防止や污れの分解 を達成することが出来ない．

さらに, 近年, 市販衣料用液体洗剂の販売額が粉末洗 剤の販売額を上回った。これらの液体洗剤は，環境配慮 型として節水(浴比・すすぎ回数抑制), 省エネ, 時短な どの傾向に向かっており, 標準濃度に溶解した時の $\mathrm{pH}$ は 中性付近になる [3-4]. そのため, 過炭酸ナトリウムが液 体洗剤に添加された場合, 漂白効果は大きく低下するこ とが推測される.さらに, 近年の洗濯機の大容量化やド ラム式の普及によって洗濯時の低浴比下が進行している と考えられる。このような新しい洗濯方法や洗剂の傾向 によって, これまで以上に移染の可能性が高くなると考 えられる。

\# corresponding author

* 北海道教育大学
一方, 酸化還元酵素であるペルオキシダーゼ $(\mathrm{POD})$ が オレンジ II などの染料を室温, 弱アルカリ領域で退色さ せることが明らかになっている[5-6]. POD を用いた染料 分解の基礎的解析として, 活性化剂を用いた染料退色速 への影響 [6-7]や染料の酸化電位の影響 $[8]$, 分解機構につ いて検討されており,オレンジ II[9], Disperse Yellow 3[10], Trypan Blue[11]などの染料の分解生成物の同定が行われ ている. また, 筆者らはPOD の従来型洗䍜の移染防止用 添加酵素として, 温度の影響[12], 洗剤成分の影響 [13]， 従来の漂白剤の影響[14]，移染防止 [15]などについて応 用的な検討を行っているが, 新しい洗濯様式に対応して いない.

従って, 本報では低浴比化・中性化の環境配虑型洗濯 によって生じる可能性がある移染に対応した POD 系の移 染防止について直接染料と酸性染料を用い, 検討を行っ た.また, これらの染料の一部は EMPA 移染モニター用 污染布にも用いられていることから, 移染モニター用污 染布の基礎デー夕を得る目的も合わせて検討した。

\section{2. 実 験}

\section{1 試薬および装置}

西洋ワサビ由来 POD (HRP) (和光純薬)の濃度は, モル 吸光係数 $1.02 \times 10^{5} \mathrm{M}^{-1} \mathrm{~cm}^{-1}(403 \mathrm{~nm})$ [16] 孝用いて算出し, 超純水で希採した。色素は C. I. Acid Blue 113(SIGMAALDRICH), C. I. Direct Blue 71 (ACROS ORGANIC) を特 
に精製せずそのまま使用した。両染料の構造を Table 1 に 示す. 色素の退色速度を増大させるHRPの活性化剂

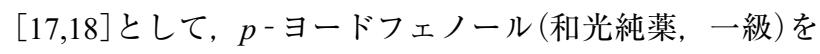
使用した. 界面活性剤はラウリン酸ナトリウムおよびポ リオキシエチレン (23) ドデシルエーテル (Brij 35) (和光純 薬 : 化学用)を使用した。その他の試薬は全て和光純薬製 試薬特級を使用した. 水はイオン交換水を一回蒸留し, 超純水処理したものを用いた.

Table 1 Structure formula of Acid Blue 113 and Direct Blue 71.

\begin{tabular}{ll}
\hline Dye & Structure formula \\
\hline
\end{tabular}

C. I. Acid Blue 113

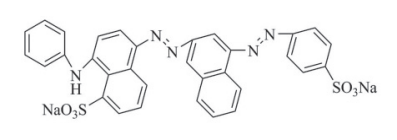

C. I. Direct Blue 71

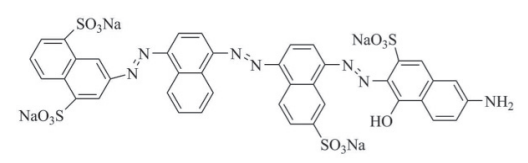

吸光度の測定には日立製紫外可視分光光度計 U-2010,

日立 131-0040 温度表示付恒温セルホールダを使用し, 光 路長 $1 \mathrm{~cm}$ の石英セルを用いた.

\section{2 操作}

HRP を用いた染料の退色反応では, 石英セルに Carmody 緩衝溶液 $1.65 \mathrm{ml}$, 染料溶液 $0.15 \mathrm{ml}, 0 \mathrm{M}$ から $1.0 \times 10^{-3} \mathrm{M} p-$ ヨードフェノール $0.3 \mathrm{ml}, 3.4 \times 10^{-7} \mathrm{M}$ HRP $0.3 \mathrm{ml}$, 界面活 性剂 $0.3 \mathrm{ml}$ を加え, $5.0 \times 10^{-4} \mathrm{M}$ から $7.5 \times 10^{-3} \mathrm{M}$ 過酸化水 素をインジェクターで $0.3 \mathrm{ml}$ 注入して反応を開始させ, 染料の可視部最大吸収波長の吸光度の経時変化を測定し た. 可視部最大吸収波長は Acid Blue 113 が 535 nm, Direct Blue 71 が577nm であった，過炭酸ナトリウムを用いた染 料の退色反応では, 石英セルに $\mathrm{pH} 11.5 \mathrm{Na}_{2} \mathrm{HPO}_{4} / \mathrm{NaOH}$ 緩 衝液 $2.25 \mathrm{ml}$, 染料溶液 $0.15 \mathrm{ml}, 2.0 \mathrm{M}$ 炭酸ナトリウム $0.3 \mathrm{ml}$ を加え, $3.0 \mathrm{M}$ 過酸化水素をインジェクターで $0.3 \mathrm{ml}$ 注入

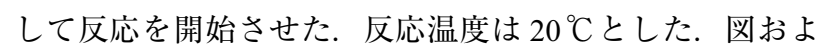
び表中の試薬濃度はいずれも終濃度を示す.

\section{3. 結果および考察}

\subsection{HRP を用いた染料退色反応の最適化}

\section{$3.1 .1 \mathrm{pH}$ の影響}

Fig. 1 に Acid Blue 113 および Direct Blue 71 の HRP を用 いた退色曲線を示す. 反応初期は一次反応であるので, 次式を用いて両染料の退色反応における退色速度定数 $k$ を算出した。

$$
\ln \left(C_{0} / C_{\mathrm{t}}\right)=k \cdot t
$$

ここで, $k\left(\mathrm{~min}^{-1}\right)$ は退色速度定数, $C_{0}$ は染料の初濃度, $C_{\mathrm{t}}$
は反応時間 $t$ における染料の濃度である. HRPを用いた Acid Blue 113 および Direct Blue 71 の退色速度定数におけ る $\mathrm{pH}$ の影響について検討した. HRP の Compound I, Compound II と酸化還元反応する Orange G や Alizarin Red S, Reactive Blue 2 などは $p$-ヨードフェノールを共存させ ることで退色反応が速やかに進行し, 退色速度定数が著 しく増大する $[17,18]$. そこで, Acid Blue 113 および Direct Blue 71 においても $p$-ヨードフェノールの有無における pHの影響について検討した. 結果を Fig. 2 に示す. Acid Blue 113 の場合, 退色速度定数は, $p$-ヨードフェノール 非共存時に $\mathrm{pH} 4.5$ で最大となった $\left(k=1.42 \mathrm{~min}^{-1}\right) . p$-ヨー ドフェノール共存時の退色速度定数は, $\mathrm{pH} 7.5$ で最大と なった $\left(k=17.1 \mathrm{~min}^{-1}\right)$. Direct Blue 113 の場合, $p$-ヨード フェノール共存時は $\mathrm{pH} 4.5\left(k=9.63 \mathrm{~min}^{-1}\right), p$-ヨードフェ ノール非共存時は $\mathrm{pH} 4.0\left(k=0.306 \mathrm{~min}^{-1}\right)$ で退色速度定数 が最大となった. $p$-ヨードフェノールを共存させること で退色速度定数が最大となる $\mathrm{pH}$ は酸性から中性側にシフ トし, 退色速度定数は, Acid Blue 113 で 12.0 倍, Direct Blue 71 で 31.5 倍となった.

以上より，p-ヨードフェノールを共存させることで反 応速度定数の極大值を示す $\mathrm{pH}$ は酸性から中性へ大きくシ フトすることがわかった．近年使用量が急増している液 体洗剤の標準使用濃度での $\mathrm{pH}$ はおよそ7前後である [3-4]ことから, 中性液体洗剂用漂白剂としての可能性が あることが明らかとなった。

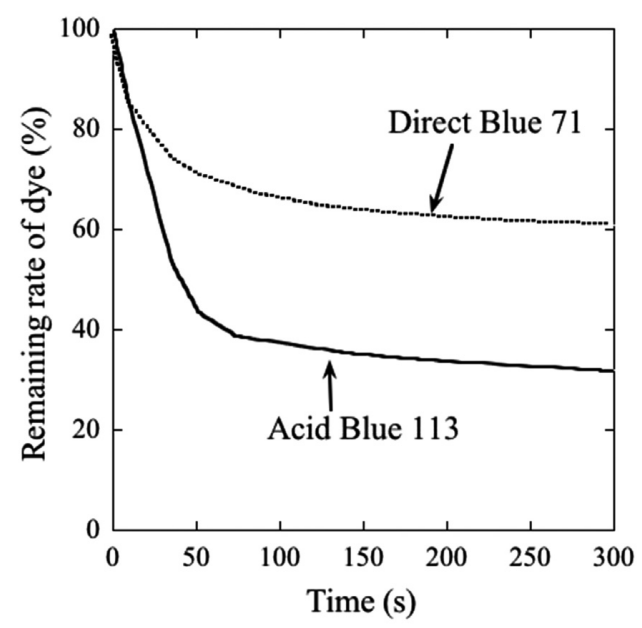

Fig. 1 Decolorization curve of Acid Blue 113 and Direct Blue 71.

$[$ Buffer $]=\mathrm{pH} 4.0$ Carmody, $[\mathrm{HRP}]=3.4 \times 10^{-8}$ $\mathrm{M},\left[\mathrm{H}_{2} \mathrm{O}_{2}\right]=7.5 \times 10^{-4} \mathrm{M}, 20^{\circ} \mathrm{C}$, Acid Blue 113 : $\left(\left[\right.\right.$ Acid Blue 113] $\left.=2.0 \times 10^{-5} \mathrm{M}\right)$, Direct Blue $71:\left([\right.$ Direct Blue 71$\left.]=3.8 \times 10^{-5} \mathrm{M}\right)$.

\subsection{2 過酸化水素濃度の影響}

次に, Acid Blue 113 および Direct Blue 71 の退色反応に おける過酸化水素濃度の影響を検討した。過酸化水素の 濃度は $5.0 \times 10^{-5} \mathrm{M}$ から $7.5 \times 10^{-3} \mathrm{M}$ とした. Fig. 3 に退色 速度定数に及ぼす過酸化水素濃度の影響を示す。いずれ も過酸化水素濃度上昇とともに退色速度定数が増大し, 
$2.5 \times 10^{-4} \mathrm{M}$ 以上でほぼ一定になった。退色率も同様の結 果となった。一方, 過酸化水素が高濃度になると POD は Compound III となり [19], POD 反応は阻害される [20]が, 過酸化水素濃度 $7.5 \times 10^{-3} \mathrm{M}$ まで退色速度定数がほぼ一定 になっていることから染料退色反応は阻害されていない と推測される.

\subsection{3 p-ヨードフェノール濃度の影響}

次に, Acid Blue 113 および Direct Blue 71 退色反応にお ける $p$-ヨードフェノール濃度の影響について検討した。 $p$-ヨードフェノール濃度は $0 \mathrm{M}$ から $1.0 \times 10^{-4} \mathrm{M}$ の範囲と した. Fig. 4 に退色速度定数および反応開始 5 分後の退色 率に及ぼす $p$-ヨードフェノール濃度の影響を示す。両染

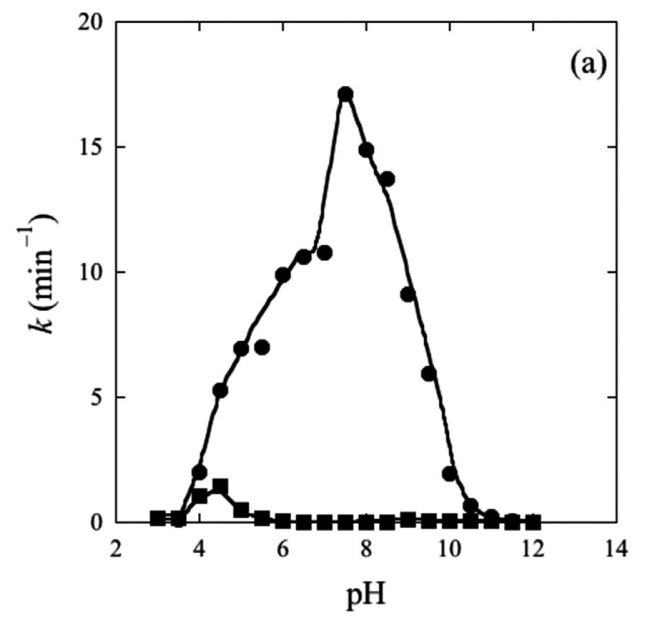

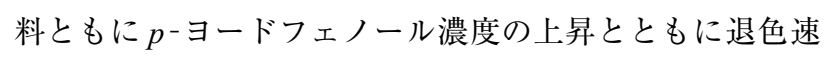
度定数が増大し， $5.0 \times 10^{-5} \mathrm{M}$ 以上で退色速度定数がほぼ 一定となった. 我々はオレンジ II の退色速度定数が $2.0 \mathrm{~min}^{-1}$ 以上で繊維への移染を防止できることを明らかに している $[15]$. 本研究で $2.0 \mathrm{~min}^{-1}$ 以上の退色速度定数が

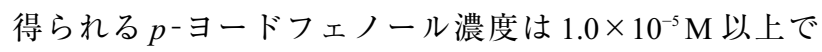
あった。退色率は両染料ともに $p$-ヨードフェノール濃度 の上昇とともに増大し, Acid Blue 113 は $p$-ヨードフェ ノール濃度 $1.0 \times 10^{-5} \mathrm{M}$ 以上, Direct Blue 71 は $2.5 \times 10^{-5} \mathrm{M}$ 以上でいずれも $75 \%$ 以上の退色率でほぼ一定となったこ とから, 吸収スペクトルの経時変化を調べた. Acid Blue 113 の結果を Fig. 5 に示す. Acid Blue 113 固有の可視部吸収

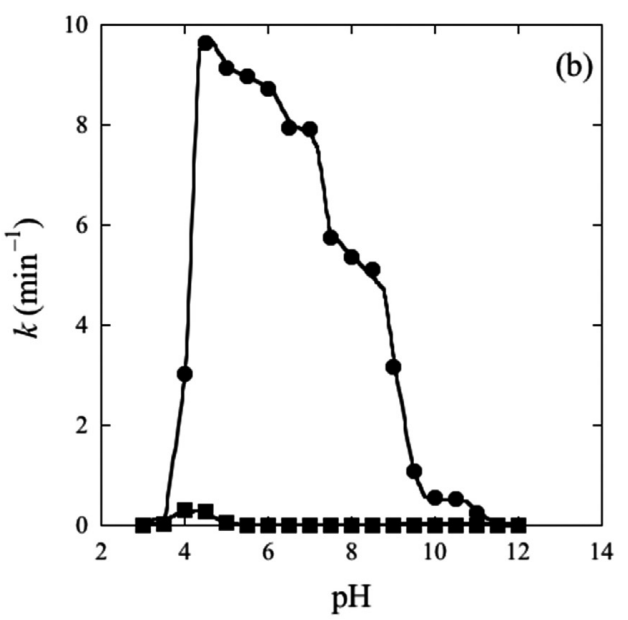

Fig. 2 Effect of pH on decolorization rate constant of Acid Blue 113 and Direct Blue 71.

$[$ Buffer $]=$ Carmody, $[\mathrm{HRP}]=3.4 \times 10^{-8} \mathrm{M},\left[\mathrm{H}_{2} \mathrm{O}_{2}\right]=7.5 \times 10^{-4} \mathrm{M}, 20{ }^{\circ} \mathrm{C}$, (a) : Acid Blue 113 $\left(\left[\right.\right.$ Acid Blue 113] $\left.=2.0 \times 10^{-5} \mathrm{M}\right),(\mathrm{b}):$ Direct Blue $71\left([\right.$ Direct Blue 71$\left.]=3.8 \times 10^{-5} \mathrm{M}\right), \mathrm{O}:$ With $p$-ioodphenol $\left([p\right.$-iodophenol $\left.]=5.0 \times 10^{-5} \mathrm{M}\right), \mathbf{\square}:$ No $p$-iodophnol.

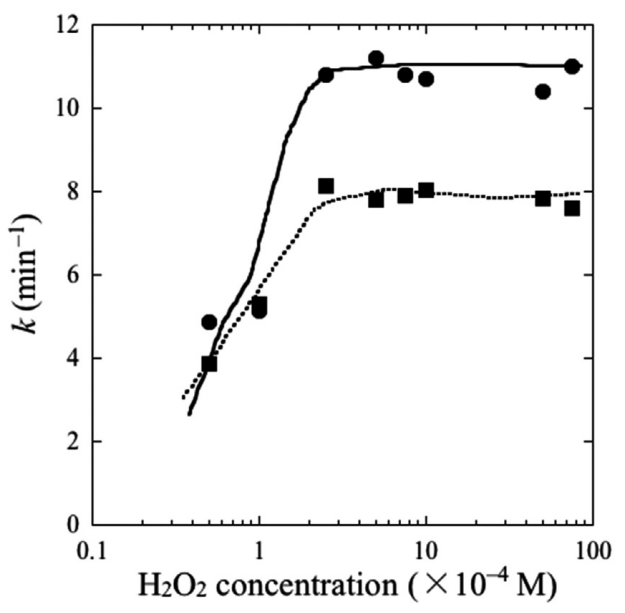

Fig. 3 Effect of $\mathrm{H}_{2} \mathrm{O}_{2}$ concentration on decolorization rate constant of Acid Blue 113 and Direct Blue 71.

[Buffer] $=\mathrm{pH} 7.0$ Carmody, $[\mathrm{HRP}]=3.4 \times 10^{-8}$ $\mathrm{M},[p$-iodophenol $]=5.0 \times 10^{-5} \mathrm{M}, 20^{\circ} \mathrm{C}, \mathrm{O}:$ Acid Blue $113\left([\right.$ Acid Blue 113$\left.]=2.0 \times 10^{-5} \mathrm{M}\right)$, : Direct Blue 71 ([Direct Blue 71] $=3.8 \times$ $\left.10^{-5} \mathrm{M}\right)$.

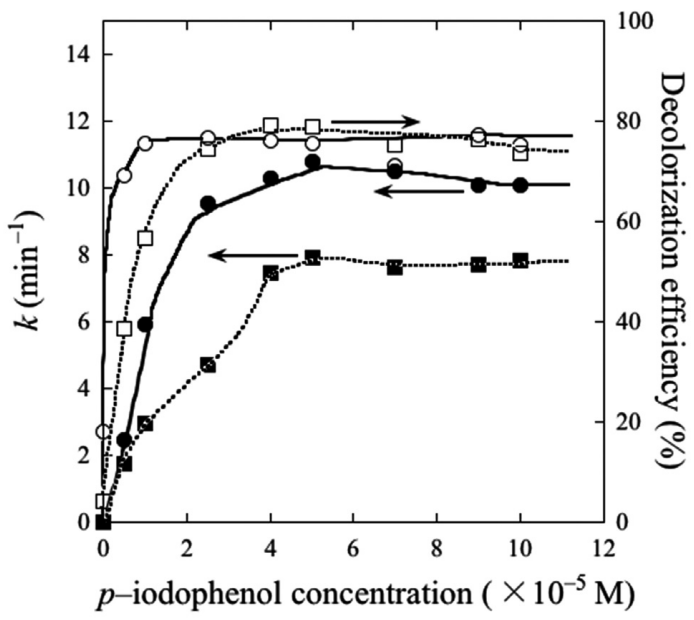

Fig. 4 Effect of $p$-iodophenol concentration on decolorization rate constant and decolorization efficiency of Acid Blue 113 and Direct Blue 71. $[$ Buffer $]=\mathrm{pH}$ 7.0 Carmody, [Acid Blue 113] = $2.0 \times 10^{-5} \mathrm{M}$, [Direct Blue 71] $=3.8 \times 10^{-5} \mathrm{M}$, $[\mathrm{HRP}]=3.4 \times 10^{-8} \mathrm{M},\left[\mathrm{H}_{2} \mathrm{O}_{2}\right]=7.5 \times 10^{-4} \mathrm{M}$, $20{ }^{\circ} \mathrm{C}$, Acid Blue 113; $\bigcirc, \quad \mathrm{O}$ : Decolorization efficiency, Direct Blue 71 ; $k, \square$ : Decolorization efficiency. 


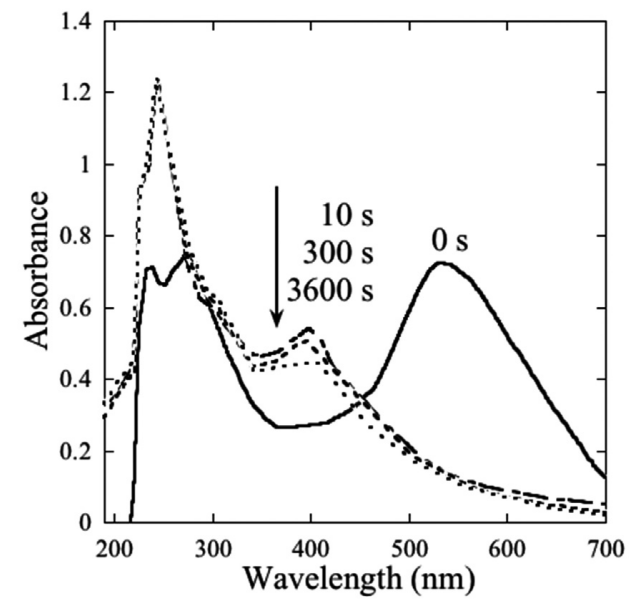

Fig. 5 Absorption spectra in the process of decolorization of Acid Blue 113.

$[$ Buffer $]=$ pH 7.0 Carmody, [Acid Blue 113] $=$ $2.0 \times 10^{-5} \mathrm{M},[\mathrm{HRP}]=3.4 \times 10^{-8} \mathrm{M},[p-$ iodophenol $]=5.0 \times 10^{-5} \mathrm{M},\left[\mathrm{H}_{2} \mathrm{O}_{2}\right]=7.5 \times 10^{-4}$ $\mathrm{M}, 20^{\circ} \mathrm{C}$.

ピーク $535 \mathrm{~nm}$ は反応時間 10 秒で消失していることから， 反応時間 10 秒で染料の共役結合は切れていると推測され る.しかしながら, 染料の可視部吸収ピークの消失と同 時に $400 \mathrm{~nm}$ 付近に吸収ピークを持つ反応生成物が確認さ れた。そのため, 測定波長と反応生成物の吸収が重なり, 退色率が低くなったと考えられる。 また， $400 \mathrm{~nm}$ 付近に 吸収ピークを持つ反応生成物の吸収は徐々に低下してい るため, 反応生成物がさらにゆっくりと分解していると 考えられる. Direct Blue 71 についても Acid Blue 113 と同 様の結果が得られた。

以上より, 低浴比化・中性化の洗濯における移染防止 を目的とした場合, $3.4 \times 10^{-8} \mathrm{M}$ HRP での Acid Blue 113 お よび Direct Blue 71 の退色反応は pH 7.0 Carmody 緩衝液, 過酸化水素濃度 $2.5 \times 10^{-4} \mathrm{M}$ 以上, $p$-ヨードフェノール濃 度 $1.0 \times 10^{-5} \mathrm{M}$ 以上が望ましいと考えられる。

一方, 従来の漂白剤である過炭酸ナトリウムを用いた Acid Blue 113 および Direct Blue 71 の退色を行い, 比較し た，過炭酸ナトリウムは酸化力が弱いため, 高温でなけ れば酸化反応が速やかに進行しない. そのため, 反応温 度を $20^{\circ} \mathrm{C}$ から $40^{\circ} \mathrm{C}$ まで変化させて退色反応の検討を 行ったところ, 退色は全く進行しなかった. 従って, $p-$ ヨードフェノール共存 HRP を用いた退色反応の有効性が 明らかとなった。

\section{2 界面活性剤添加の影響}

移染防止剤として洗剤へ HRP を添加することを考慮し た場合に, 界面活性剤の影響について検討しておく必要 がある. そのため, Acid Blue 113 および Direct Blue 71 の 退色反応系に界面活性剂として陰イオン界面活性剤のラ ウリン酸ナトリウムと非イオン界面活性剤の Brij 35 を添 加し，両染料の退色反応に及ぼす影響を検討した．ラウ リン酸ナトリウムおよび Brij 35 の $\mathrm{cmc}$ は $1.1 \times 10^{-2} \mathrm{M}$, $6.0 \times 10^{-5} \mathrm{M}$ であるので, 本反応系では界面活性剂の濃度
を $\mathrm{cmc}$ の 0 倍から 3.0 倍の範囲とした.

Fig. 6 に退色速度定数に及ぼす界面活性剤濃度の影響を 示す.いずれの染料および界面活性剤の組み合わせも濃 度上昇とともに退色速度定数は減少し, Acid Blue 113 に ラウリン酸ナトリウムを $\mathrm{cmc}$ の 1.5 倍添加することで退 色速度定数の減少率は $12.6 \%\left(k=9.43 \mathrm{~min}^{-1}\right)$, Brij 35 を $\mathrm{cmc}$ の 1.5 倍添加することで $21.8 \%\left(k=8.43 \mathrm{~min}^{-1}\right)$, Direct Blue 71 はそれぞれ $38.3 \%\left(k=4.88 \mathrm{~min}^{-1}\right), 22.5 \%\left(\mathrm{k}=6.13 \mathrm{~min}^{-1}\right)$ となった．界面活性剂の添加による反応速度に及ぼす影 響について, さらに検討が必要である.

\section{4. 総 括}

酸性染料 Acid Blue 113 および直接染料 Direct Blue 71 を 用いた HRP による退色反応について，環境配慮型洗濯に おける移染防止剂としての実用化を目的として検討した。

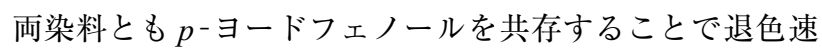
度定数が大きく上昇した，液体洗剂への添加剤としての 応用を考慮し，緩衝液を 7.0 Carmody 緩衝液とした。また， 過酸化水素濃度 $2.5 \times 10^{-4} \mathrm{M}, p$-ヨードフェノール濃度 $1.0 \times 10^{-5} \mathrm{M}$ 以上で移染を防止できる退色速度定数が得ら れることが明らかとなった，反応中間生成物が $400 \mathrm{~nm} に$ 吸収を持つため退色率は $80 \%$ を下回ったが, 染料の最大 吸収波長のピークが消失していることから, 両染料共に 分解反応は進行していることがわかった。 また，過炭酸 ナトリウムを用いた Acid Blue 113 および Direct Blue 71 の 退色反応を HRP 系と比較したところ, 過炭酸ナトリウム による退色反応はほとんど進行しなかった，従って，液

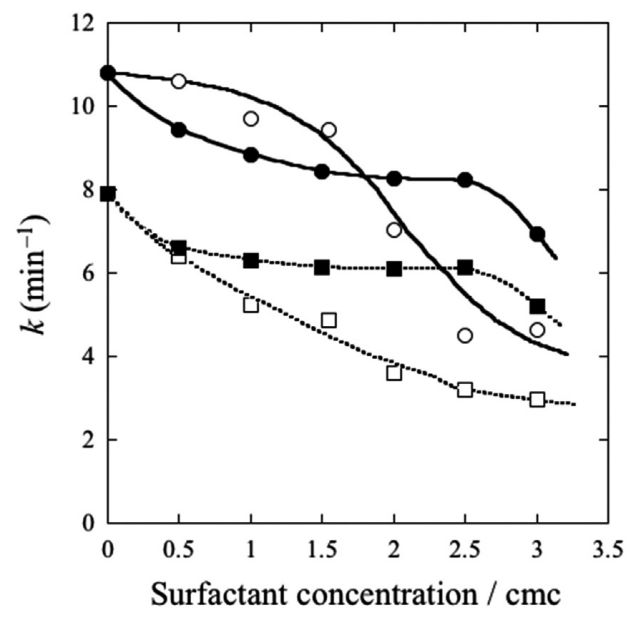

Fig. 6 Effect of surfactant concentration on decolorization rate constant of Acid Blue 113 and Direct Blue 71.

$[$ Buffer $]=\mathrm{pH} 7.0$ Carmody, $[\mathrm{HRP}]=3.4 \times 10^{-8}$ $\mathrm{M},[p$-iodophenol $]=5.0 \times 10^{-5} \mathrm{M},\left[\mathrm{H}_{2} \mathrm{O}_{2}\right]=7.5 \times$ $10^{-4} \mathrm{M}, 20{ }^{\circ} \mathrm{C}, \mathrm{O}$ : Acid Blue $113 /$ Brij 35 $\left(\left[\right.\right.$ Acid Blue 113] $\left.=2.0 \times 10^{-5} \mathrm{M}\right), \bigcirc$ Acid Blue 113 / Sodium laurate $([$ Acid Blue 113] $=2.0 \times$ $10^{-5} \mathrm{M}$ ), $\square$ : Direct Blue $71 /$ Brij 35 ([Direct Blue 71] = 3.8 $\left.\times 10^{-5} \mathrm{M}\right), \square:$ Direct Blue $71 /$ Sodium laurate $\left([\right.$ Direct Blue 71$\left.]=3.8 \times 10^{-5} \mathrm{M}\right)$. 
体洗剤の移染防止剤としての HRP の添加有効性が見出さ れた。

ラウリン酸ナトリウムおよび Brij 35 を Acid Blue 113 お よび Direct Blue 71 の退色反応に添加した場合, 両染料と も, 界面活性剂濃度の上昇とともに退色速度定数が低下 した. $\mathrm{cmc}$ の 1.5 倍濃度を添加することで, 退色速度定数 が約 10\% から $40 \%$ 低下した.

本研究の一部は科研費 ・ 基盤研究 (A) (23240101)の助成 を受けたものである。

\section{文 献}

1. M. Morita, E. Komatsu, T. Kamidate and H. Watanabe, Sen'i Gakkaishi, 53, 471 (1997).

2. R. Ohura, J. of Home Economics of Japan, 40, 913 (1989).

3. A. Higashi and M. Morita, Journal of Hokkaido University of Education (Natural Science), 63, 1 (2013).

4. M. Sasaki and M. Fuji, Journal of Tokyo Kasei Gakuin University, 52, 33 (2012).

5. M. Morita, R. Ito, T. Kamidate and H. Watanabe, Text. Res. J. 66, 470 (1996).

6. M. Morita, T. Kamidate, T. Shibata and H. Watanabe, J. Jpn. Oil Chem. Soc., 46, 807 (1997).

7. M. Morita, T. Watanabe and A. Higashi, Sen'i Gakkaishi, 69, 147 (2013).
8. T. Kamidate, T. Shibata, H. Watanabe and M. Morita, J. Jpn. Oil Chem. Soc., 48, 497 (1999).

9. M. Morita, E. Yamaguchi, E. Komatsu, R. Ito, T. Kamidate and H. Watanabe, J. Jpn. Oil Chem. Soc. 48, 793 (1999).

10. J. T. Spadaro and V. Renganathan, Arch. Biochem. Biophys., 312, 301 (1994).

11. U. Kalsoom, S. S. Ashraf, M. A Meetani, M. A Raul and H. N. Bhatti, Chemistry Central Journal 93, 7 (2013).

12. A. Higashi and M. Morita, Sen'i Gakkaishi, 70, 100 (2014).

13. M. Morita, E. Yamaguchi, T. Kamidate and H. Watanabe, Jpn. Oil Chem. Soc., 46, 573 (1997).

14. M. Morisaki, M. Morita and T. Watanabe, Sen'i Gakkaishi, 66, 56 (2010).

15. M. Morita, E. Komatsu, T. Kamidate and H. Watanabe, Sen'i Gakkaishi, 53, 289 (1997).

16. B. B. Kim, V. V. Pisarev and A. M. Egorov, Anal. Biochem., 199, 1 (1991).

17. M. Morita, T. Kamidate, T. Shibata and H. Watanabe, $J$. Jpn. Oil Chem., 46, 807 (1997).

18. E. Komatsu and M. Morita, Bulletin of Tenshi College, $\mathbf{1}$, 45 (2001).

19. R. Nakajima and I. Yamazaki, J. Biol. Chem., 262, 2576 (1987).

20. S. X. Chen and P. Schopfer, Eur. J. Biochem., 260, 726 (1999). 